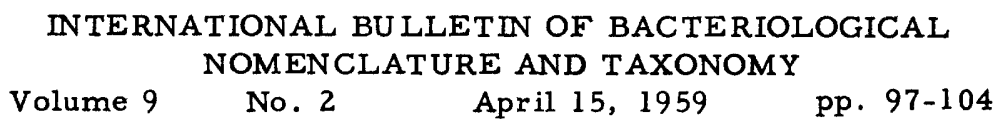

\title{
OUTLINE OF A COMPARATIVE STUDY OF CRITERIA USED IN CHARACTERIZATION OF THE ACTINOMYCETES
}

\author{
Dr. E. Kuster, Secretary \\ International Subcommittee on \\ Taxonomy of the Actinomycetales \\ Dept. of Industrial Microbiology \\ University College \\ Dublin
}

In the course of the meeting on Streptomycetes in Stockholm, August, 1959, the participants formulated a plan for a common experiment which should establish the reproductivity of the stable properties used in the characterization of streptomycetes. In the various laboratories, the same strains on standardized culture media are to be examined and judged at determined intervals for the expression of certain properties. The following outline of the plan was distributed to those who agreed to participate in the experiment. Thirty four individuals and laboratories agreed to participate.

\section{Outline of Experimental Plan}

General Experimental Conditions:

Altogether, the experiments will be carried out three times in a dark room with a temperature of $28^{\circ} \mathrm{C}$. The interval between repetitions is 2 months, during which the strains will be reinoculated three times. For a growing period of 12 days the cultures are stored in a dark room with a temperature of $28^{\circ} \mathrm{C}$. For the last 8 days they are stored at room temperature. From these culture tubes the next passage is inoculated. From the last passage ( $3 \mathrm{rd}$ one) the experimental plates and tubes are inoculated. The standardized medium for storage and the various stages is oatmeal agar, from which the actual experimental plates or, as the case may be, tubes are inoculated. In those cases, in which the formation of aerial mycelia on oatmeal agar is very weak or is entirely absent, glycerol-glycine agar is suggested for the standardized medium. Freshly prepared culture medium should always be used for each inoculation. 
Petri dishes having a diameter of $9 \mathrm{~cm}$ with $15 \mathrm{cc}$ culture medium should be used. Each plate will be inoculated with a fresh platinum-wire loop of spores.

\section{Experimental Strains:}

From his collection, Prof. Baldacci (Milano) is selecting 25 strains which, is possible, should represent all of his 21 series. The strains will be sent simultaneously (beginning of December, 1958) by him to all participants of the experiment. The strains are numbered consecutively from 1 to 25 . Should some participants be able to work with only a few of the strains, only the first strains should be used, e.g. strains 1 to 10 , or 1 to 15 .

\section{Culture Media:}

1. Oatmeal agar: $20 \mathrm{~g}$ of oatmeal will be cooked in 1000 cc of tap water for $20 \mathrm{~min}$. and filtered through cheesecloth, the filtrate should then be filled up to $1000 \mathrm{cc}$; addition of $18 \mathrm{~g}$ agar. Adjust to $\mathrm{pH} 7.2$ with $\mathrm{NaOH}$.

2. Glycerol-glycine agar:

(n. Lindenbein)

$\begin{array}{lr}\text { Glycerol (Merck) } & 20.0 \mathrm{~g} \\ \text { Glycine (Merck) } & 2.5 \mathrm{~g} \\ \mathrm{~K}_{2} \mathrm{HPO}_{4} \text { (Merck) } & 1.0 \mathrm{~g} \\ \mathrm{NaCl} \text { (Merck) } & 2.0 \mathrm{~g} \\ \mathrm{MgSO}_{4} \cdot 7 \mathrm{H}_{2} \mathrm{O} & 0.5 \mathrm{~g} \\ \mathrm{FeSO}_{4} \cdot 7 \mathrm{H}_{2} \mathrm{O} & 0.1 \mathrm{~g} \\ \mathrm{CaCO}_{3} & 0.2 \mathrm{~g} \\ \text { Agar (Difco) } & 18.0 \mathrm{~g} \\ \text { Aq.dest. } & 1000 \mathrm{cc} \\ \text { Adjust to pH } 7.2 \text { with } \mathrm{NaOH} . & \end{array}$

3. Inorganic Salts-Starch Agar:

(n. Pridham, 1957)

Solution I: Difco soluble starch $10.0 \mathrm{~g}$ Make a paste of the starch with a small amount of cold tap water and bring to a volume of $500 \mathrm{ml}$. 
B ACTERIOLOGICAL NOMENCLATURE AND TAXONOMY

\begin{tabular}{|c|c|c|}
\hline Solution II: & $\begin{array}{l}\mathrm{K}_{2} \mathrm{HPO}_{4} \text { (Merck) } \\
\mathrm{MgSO}_{4} \cdot 7 \mathrm{H}_{2} \mathrm{O} \\
\mathrm{NaCl} \\
\left(\mathrm{NH}_{4}\right)_{2} \mathrm{SO}_{4} \\
\mathrm{CaCO}_{3} \\
\text { Tap water }\end{array}$ & $\begin{array}{l}1.0 \mathrm{~g} \\
1.0 \mathrm{~g} \\
1.0 \mathrm{~g} \\
2.0 \mathrm{~g} \\
2.0 \mathrm{~g} \\
500 \mathrm{ml}\end{array}$ \\
\hline
\end{tabular}

Do not adjust $\mathrm{pH}$. Mix the starch suspension and the salts solution. Add agar (Difco) $20.0 \mathrm{~g}$.

4. Glycerol-asparagine agar:

$\begin{array}{lr}\text { Glycerol (Merck) } & 10.0 \mathrm{~g} \\ \text { Asparagine (Merck) } & 1.0 \mathrm{~g} \\ \mathrm{~K}_{2} \mathrm{HPO}_{4} \text { (Merck) } & 1.0 \mathrm{~g} \\ \text { Agar (Difco) } & 20.0 \mathrm{~g} \\ \text { Tap water } & 1000 \mathrm{cc} \\ \text { Adjust to pH } 7.0 \text { with } \mathrm{NaOH} . & \end{array}$

5. Peptone agar:

$\begin{array}{lr}\text { Bacto-Tryptone (Difco) } & 1.0 \mathrm{~g} \\ \text { Bacto-Yeast Extract (Difco) } & 1.0 \mathrm{~g} \\ \mathrm{NaCl} & 8.5 \mathrm{~g} \\ \text { Agar } & 17.0 \mathrm{~g} \\ \text { Tap water } & 1000 \mathrm{cc}\end{array}$

Sterilization of all media: 20 minutes at $120^{\circ}$ C. $\mathrm{pH}$ is adjusted before sterilization.

Examination and Judgment of the Properties

1. Morphology of the aerial mycelium and the spores:

For the observation of the aerial mycelium, 5 Petri dishes with Starch-Ammoniumsulphate-Agar will be used for strain and repetition. The observation should be made on ripe aerial mycelia with a good spore formation. To establish the most favorable data for observation, a direct observation with a light microscope will be made on the 10 th, 15 th, and 20th days of growth; each time one plate will be used which will be discarded after the observation.

The form of the sporophores will be designated according to the nomenclature from Pridham (modified according to Baldacci): 
Rectus

Rectus-flexibilis

Retinaculum-Apertum

Spira

Monoverticillus

Monoverticillus-Spira

Biverticillus

Biverticillus-Spira straight

flexuous

open loops

spirals

The forms observed should, if possible, be designated. Photographs are also desired of typical and characteristic forms and of doubtful cases.

If an electron microscope is available, it is desirable to make print preparations from the same plate which is observed under the light microscope.

The results should be judged according to the designations:

$$
\begin{aligned}
& \text { smooth } \\
& \text { spinous } \\
& \text { hairy }
\end{aligned}
$$

2. Color of the aerial and substratum mycelia:

For judging the color of the aerial and sub stratum mycelia, 3 Petri dishes with glycerol-asparagine agar are used for each strain and repetition. The judging should be made after 10,15 and 20 days. In those cases, in which an aerial mycelium is not formed, the upper side of the substratum mycelium is judged. In every case, however, the color of the reverse side will be designated as the color of the substratum mycelium. The judgment of color is carried out according to the 10 basic colors: colorless, white, yellow, orange, red, blue, green, gray, brown, and black. Intermediate tones are designated by putting the predominant color second and by underlining it on the file card. In the designation of the color, the age of the culture should be given in which the color was observed or, as the case may be, in which a change of color did not appear.

3. Formation of a melanoid pigment:

For the judging the formation of a melanoid pigment, 3 tubes with peptone agar (agar slant) will be used for each strain and repetition. The strains are inoculated in lines. The determination should be made after 2 and 4 days with 


\section{BACTERIOLOGICAL NOMENCLATURE}

Page 101

AND TAXONOMY

+ or - in comparison to an uninoculated control tube. Only the appearance of a brown-black coloring of the agar will be noted. The strength of the brown coloring need not be given.

\section{Evaluation of the Experiment}

Dr. Wallhdusser (Frankfurt/M. - Germany) will send each participant in the experiment 1 file card for each strain.* On this card, which has English notation, the entries of the properties observed are to be made separately for each repetition. On the back of the file card there is a space for special remarks as e.g. no growth on the precribed culture medium, use of a substitute culture medium, peculiarities in the morphology. After termination of the experiment, the completed cards will be returned to Wallhdusser for statistical evaluation. The concluding report will be compiled by Klister.

Schedule:

Beginning of Jan., 1959: Carrying out of the lst test. Beginning of March, 1959: Carrying out of the 2nd test. Beginning of May, 1959: Carrying out of the 3rd test. Until July 1, 1959: Return of the file cards to Dr. Wallhalusser.

October 1, 1959: Distribution of the condensation of the result and the experimental report.

*See p. 65 This BULLETIN. 
Page 102

INTER NATIONAL BULLETIN

\section{List of Participants}

1. Arishima, Dr. Labor. in Meiji Seika Co., Kawasaki, Kanagawa-ken, Japan (25 strains)

2. Backus, Dr. E.J. Lederle Labor. Amer. Cyanamid Co., Pearl River, N.Y., U.S.A. (25 strains)

3. Baldacci, Prof. Ist. Patol. Vegetale, Univ. Milano, Dr. E. Via Celoria 2, Milano, Italy (25 strains)

4. Ciferri, Prof. Dr. Ist. Botan. Univ. Pavia, P. O. $R$. Box 165, Pavia, Italy (25 strains)

5. Frommer, Dr.W. Farbenfabrik Bayer, WuppertalElderfeld, Germany (25 strains)

6. Gause, Prof. Dr. Inst. of Antibiotics, Acad. Med. G.F. Sci. , Bolshaja Pirogovskaja, Moscow, U.S.S.R. (25 stralns)

7. Harada, Dr. Labor. Kyowa Fermentation Co., Mishima, Shizuoka-ken, Japan (25 strains)

8. Hata, Dr. Kitasoto Inst., Minato-ku, Tokyo, Japan (25 strains)

9. Hutter, Dr. R. Inst. Spez. Botanik Eidg. Tech. Hochsch, Universitutsstr. 2, Zurich, Switzerland ( 25 strains)

10. Joly, Dr. S. Inst. Zimotecnio, Univ. de São Paulo, Piracicaba/São Paulo, Brazil (25 strains)

11. Knd11, Prof. Dr. Inst. Mikrobiol. u. experimentelle Therapie, Jena, Germany (25 strains)

12. Komatu, Dr. Inst. for Infect. Diseases, Tokyo Univ., Minato-ku, Tokyo, Japan (25 strains)

13. Krassilnikov, Prof. Inst. of Microbiol., Acad. Sci. Dr. N.A. U.S.S.R., Leninskij Prospekt 33, Moscow, U.S.S.R. (25 strains)

14. Kurylowicz, Prof. Inst. Antibiotikaforsch., Zurawai W. 6/12, Warazawa, Poland (25 strains)

15. Mach, Dr. F.

Botan. Inst. Univ., Grimmer Strasse 88, Greifswald, Germany 25 strains) 
BACTERIOLOGICAL NOMENCLATURE AND TAXONOMY

16. Nakazawa, Dr.K. Inst. of Fermentation of Osaka Takeda Pharm. Co., Higaski Yodogawa-ku, Osaka, Japan (25 strains)

17. Nishimura, Dr. Labor. in Shionogi Pharm. Co., Dosho-machi, Osaka, Japan (25 strains)

18. Nomi, Dr. Inst. of Fermentation Technology, Hiroshima University, Hiroshima, Japan (25 strains)

19. Ohara, Dr. Yamanashi Univ., Yamanashi, Japan (25 strains)

20. Okami, Dr. Y. National Inst. Health, Minato-ku, Tokyo, Japan (25 strains)

21. Otuki, Dr. Ochanamizu Woman's Univ., Otuka, Tokyo, Japan (10 strains)

22. Pfennig, Dr. N. Inst. Mikrobiol. Univ., Gosslerstrasse 16, Göttingen, Germany (10 strains)

23. Pinnert, Dr. S. Ste. Rhone-Poulenc, 9, Quai Jules-Guesde, Vitry-sur-Seine, France (25 strains)

24. Pridham, Dr. Northern Utiliz. Res. Div., Agric. T.G. Res. Serv., Peoria, Ill. U.S. A. (25 strains)

25. Sakai, Dr. Labor. in Fujisawa Pharm. Co., Honcho, Nihonbashi, Tokyo, Japan (25 strains)

26. Sanchez-Marroquin, Miami 40, Mexico 18/D. F., MexDr. A. ico ( 25 straing)

27. Shiobu, Dr. Osaka Univ. Liberal ArtEducation (Hirano Branch) Higashi Sumiyoshi-ku, Osaka, Japan(25 strains)

28. Szabo, Dr. J. Inst. f. Bodenbiologie, Ungar. Akad. Wiss., Sopron, Hungary (10 strains)

29. Tešić, Prof. Dr. Inst. Microbiol. du Sol, Univ. Beo$\mathrm{Z}$. grad, Kojacka 1, Beograd, Yugoslavia (25 strains)

30. Tomosugi, Dr. Pfizer Co., Taito, Japan (25 strains)

31. Umezawa, Dr. Inst. Appl. Microbiol., Tokyo, Univ., Tokyo, Japan (25 strains) 
Page 104

INTERNATIONAL BULLETIN

32. De Vries, Dr. Centraalbureau voor SchimmelculG.A. tures, Baarn, Netherlands ( 10 strains)

33. Waksman, Prof. Inst. Microbiol., Rutgers Univ., S. A. New Brunswick, N.J., U.S.A. (25 strains)

34. Wallhtusser, Dr. Mikrobiol. Labor., Farbwerke K. H. Hoechst AG, Frankfurt/M., Hoechst, Germany (25 strains) 